\title{
EFFECT OF SILICON ON SUNFLOWER GROWTH AND NUTRIENT ACCUMULATION UNDER LOW BORON SUPPLY
}

Savić, J. ${ }^{*}$ and Marjanović-Jeromela, A. ${ }^{2}$

${ }^{1}$ Faculty of Agriculture, University of Belgrade, Nemanjina 6, Zemun,

Republic of Serbia

2 Institute of Field and Vegetable Crops, M. Gorkog 30, Novi Sad,

Republic of Serbia

Received: January 08, 2013

Accepted: June 10, 2013

SUMMARY

Study was focused on effect of silicon (Si) on growth and nutritional status of sunflower (Helianthus annuus L.) under low boron (B) external supply. Plants were grown under controlled environmental conditions in nutrient solutions with two low B treatments $(0.2 \mu \mathrm{M} \mathrm{B}$ and $0.5 \mu \mathrm{M} \mathrm{B})$ with or without addition of Si and control treatment containing sufficient B supply. Shoots growth was only slightly affected by Si supply while accumulation of B in fully developed leaves was significantly higher only at $0.5 \mu \mathrm{M}$ B. In roots, nutrients contents were relatively constant, while accumulation of all nutrients in leaves was affected by addition of Si. Differences were significant only in $\mathrm{K}, \mathrm{Fe}$ and Mo between treatments $0.5 \mu \mathrm{M}$ B and $0.5 \mu \mathrm{M}$ B with Si added and in $\mathrm{Zn}$ between both treatments. In comparison with other studies, results confirmed that plant species show different response to $\mathrm{Si}$ application. Interaction of $\mathrm{B}$ and $\mathrm{Si}$ should be involved in further research in B deficiency in sunflower.

Key words: boron deficiency, mineral elements, silicon, sunflower

\section{INTRODUCTION}

Boron (B) and silicon (Si) are elements similar in many chemical characteristics. Both are taken up by plant roots in the form of weak, undissociated acids (Marschner, 2012). Long time ago it has been shown that B is essential element for higher plants and its role in plant physiology is studied the least among all micronutrients (Mengel et al., 2001). Under conditions of B deficiency plant growth is inhibited due its role in cell wall formation as well as limited mobility within most of the plants (Brown et al., 1997). Cakmak et al. (1995) showed that B is very

* Corresponding author: Phone: +381112615316; Fax: +381113161987; e-mail: jaca@agrif.bg.ac.rs 
important for membrane stability, but its role in phenols and auxin metabolism, sinthesis of RNK still is not clear (Römheld et al., 1991).

The essentiality of silicon (Si) for higher plants has been shown only in a few species, such as rice and sugarcane and this is why Si fertilizers are applied to these crops (Ma, 2004). Beneficial effects of Si on plant growth, development, yielding and disease resistance have been observed in both monocots and dicots (Ma, 2004; Epstein, 1999). Seems that $\mathrm{Si}$ is the only element that can enhance plant resistance to multiple stress. Proposed mechanisms for Si-enhanced resistance to diseases as well as effectiveness of $\mathrm{Si}$ in controlling plant diseases in different crops are well described by Ma (2004) and Ma et al. (2006).

Interaction of $\mathrm{B}$ and $\mathrm{Si}$ in higher plants has been studied, but results regarding role of $\mathrm{Si}$ in growth of $\mathrm{B}$ deficient plants are limited. Liang et al. (1994) showed direct competitive interaction of $\mathrm{B}$ and $\mathrm{Si}$ for oilseed rape. Under conditions of $\mathrm{B}$ deficiency Si enhanced B uptake and accumulation while lowered both under normal and toxic B external supply. Numerous studies showed that $\mathrm{Si}$ ameliorates B toxicity. Recently Kaya et al. (2011) obtained lower B accumulation as well as Si effect on reduction of antioxidant enzymes activity in tomato. Barley and wheat tolerance to high soil B in the presence of Si was shown by Gunes et al. (2007) and Inal et al. (2009), respectively.

Low B soils are spread in more than eighty countries around the world (Shorrocks, 1997) and agriculture production is often affected by B deficiency causing yield loss. Sunflower (Helianthus annuus L.) is sensitive to B deficiency, also more in the reproductive stage (Asad, 2002). Low B in soil often causes seed set reduction in sunflower. Recent study by Ozturk et al. (2011) showed a high positive correlation between B concentrations in leaves of sunflower grown on low B soil and applied B doses. Reddy et al. (2003) highlighted that sunflower harvest index can be improved by applying of B. Cases of B deficiency in sunflower based on response to B application were recorded in many countries including ex Yugoslavia (Shorrocks, 1997).

The aim of the study was to investigate the effect of $\mathrm{Si}$ on sunflower growth, nutrients uptake and accumulation under low B external supply.

\section{MATERIALS AND METHODS}

\section{Plant material, growth conditions and treatments}

Sunflower (cv. Duško) seeds were germinated in quartz send at $25^{\circ} \mathrm{C}$ with addition of saturated $\mathrm{CaSO}_{4}$ solution. Five days after germination seedlings were transferred to continuously aerated standard nutrient solution ( 4 plants per 2.51 plastic pot) containing $(\mathrm{mM}): 0.7 \mathrm{~K}_{2} \mathrm{SO}_{4}, 0.1 \mathrm{KCl}, 2.0 \mathrm{Ca}\left(\mathrm{NO}_{3}\right)_{2}, 0.5 \mathrm{MgSO}_{4}, 0.1 \mathrm{KH}_{2} \mathrm{PO}_{4}$ and $(\mu \mathrm{M}) 0.5 \mathrm{MnSO}_{4}, 0.5 \mathrm{ZnSO}_{4}, 0.2 \mathrm{CuSO}_{4}, 0.01\left(\mathrm{NH}_{4}\right)_{6} \mathrm{Mo}_{7} \mathrm{O}_{24}$ and $20 \mathrm{Fe}(\mathrm{III})-$ EDTA. B was supplied as $\mathrm{H}_{3} \mathrm{BO}_{3}$ at two deficient low supplies of 0.2 and $0.5 \mu \mathrm{M}$, 
including control treatment with $10 \mu \mathrm{M} \mathrm{B}$. One half of the plants grown under two levels of low B concentration were supplied with $1.5 \mathrm{mM} \mathrm{Si}$ as $\mathrm{Si}(\mathrm{OH})_{4}$. It was prepared by passing $\mathrm{Na}_{2} \mathrm{SiO}_{3}$ through a plastic column filled with cation-excange resin (Amberlite IR-120 $\mathrm{H}^{+}$form, Fluka, Deisenhofen, Germany).

Plants were grown under controlled environmental conditions with a light/dark regime of $16 / 8 \mathrm{~h}$, air temperature of $25^{\circ} \mathrm{C}$, photon flux density of around $300 \mu \mathrm{mol}$ $\mathrm{m}^{-2} \mathrm{~s}^{-1}$ and a relative humidity of $70 \%$. Nutrient solutions were renewed twice per week. Plants were harvested after two weeks and samples were taken for analysis.

\section{Analytical methods}

Roots and shoot were dried at $70^{\circ} \mathrm{C}$ and dry weight was determined. Afterwards plant material was microwave digested with $3 \mathrm{ml}$ of $\mathrm{HNO}_{3}$ and $2 \mathrm{ml}$ of $\mathrm{H}_{2} \mathrm{O}_{2}$. B and other elements (P, K, Ca, Mg, S, Fe, $\mathrm{Zn}, \mathrm{Mn}, \mathrm{Cu}, \mathrm{Mo}$ ) in the roots and fully developed leaves were determined by ICP-OES.

\section{Statistical analyses}

Data were subjected to ANOVA and the means were compared by Dankan's multiple range test at $p \leq 0.05$, using COSTAT software package.

\section{RESULTS AND DISCUSSION}

Root and shoot dry weight of sunflower plants was differing between treatments, but not significantly. In all treatments, including control root weight was around $100 \mathrm{mg}$ per plant (Figure 1). Seems that low B supply of $0.2 \mu \mathrm{M}$ B and 0.5 $\mu \mathrm{M} B$ in nutrient solution didn't cause a strong reduction of root growth. Shoot growth was slightly decreased under B deficiency treatments $0.2 \mu \mathrm{M}$ B and $0.5 \mu \mathrm{M}$ $\mathrm{B}$ (around $650 \mathrm{mg}$ per plant) compared to control (around $750 \mathrm{mg}$ per plant), but addition of Si did not enhance significantly plants growth (Figure 1). Rogalla et al., (2002) presented similar observations in cucumber plants grown under conditions of severe deficiency of $0.02 \mu \mathrm{M}$ B. Cucumber plants were strongly affected by B deficiency and Si treated plants grew slightly better than plants not treated with $\mathrm{Si}$, but this effect was not significant. Two low B concentrations applied in presented study were chosen with aim to avoid concentration effect which might appear due to inhibition of plant growth. Very low B concentrations such as $0.1 \mu \mathrm{M}$ cause strong inhibition of plant growth, as showed for oilseed rape by Savic et al. (2012). On the other side, Liang et al., (1994) showed positive effect of Si on oilseed rape grown in nutrient solutions with $0.025 \mu \mathrm{g} \mathrm{B} / \mathrm{ml}$ (calculated by authors $0.4 \mu \mathrm{M} \mathrm{B}$ ). In addition, increased levels of Si slightly decreased root length under $0.4 \mu \mathrm{M}$ B treatment, while root dry weight was increased.

As it was expected, B concentration was the highest in both root and shoot in control treatment (Figure 2). In roots, B concentration was significantly higher in control in comparison to other treatments $(p \leq 0.05)$, but diferences between both 


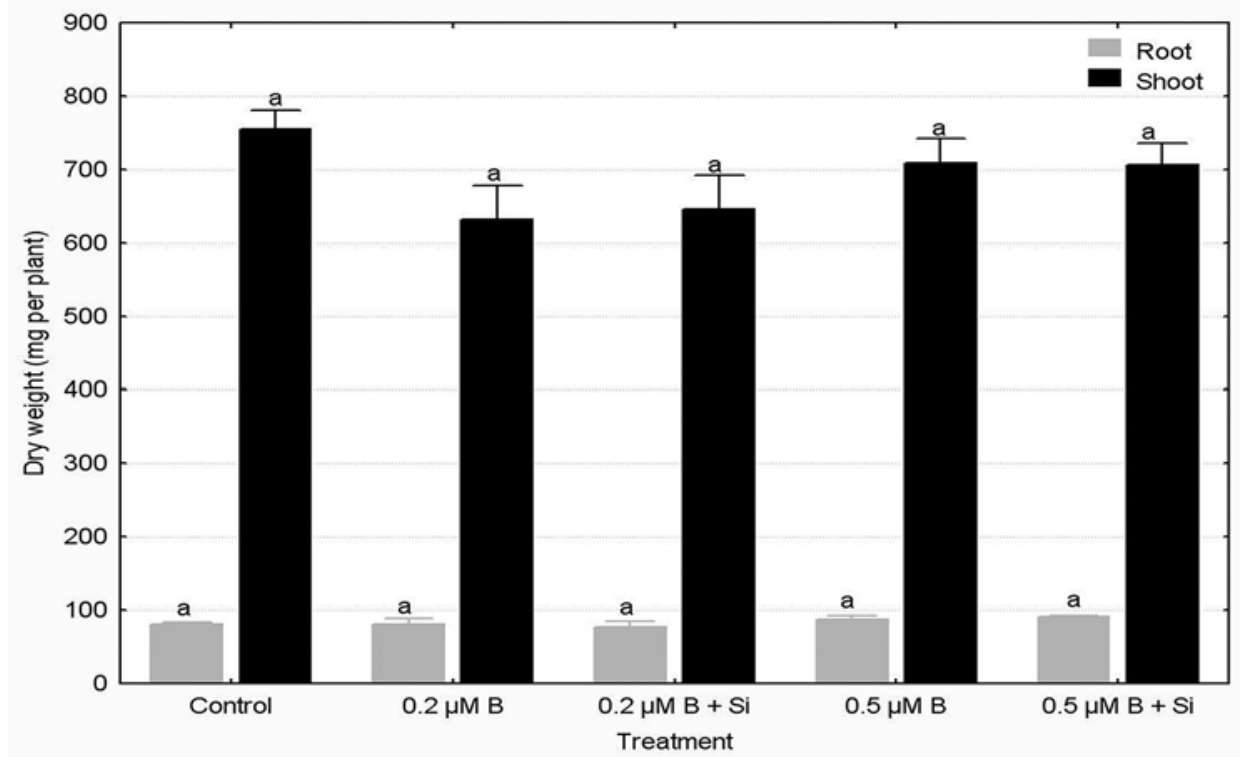

Figure 1: Effect of Si on root and shoot dry weight of sunflower plants subjected to low $B$ external supply $(0.2 \mu M B$ and $0.5 \mu M B)$. Si concentration in nutrient solution was $1.5 \mathrm{mM}$. Data are means $(n=4) \pm S D$. Significant differences at $p \leq 0.05$ are indicated by different letters.

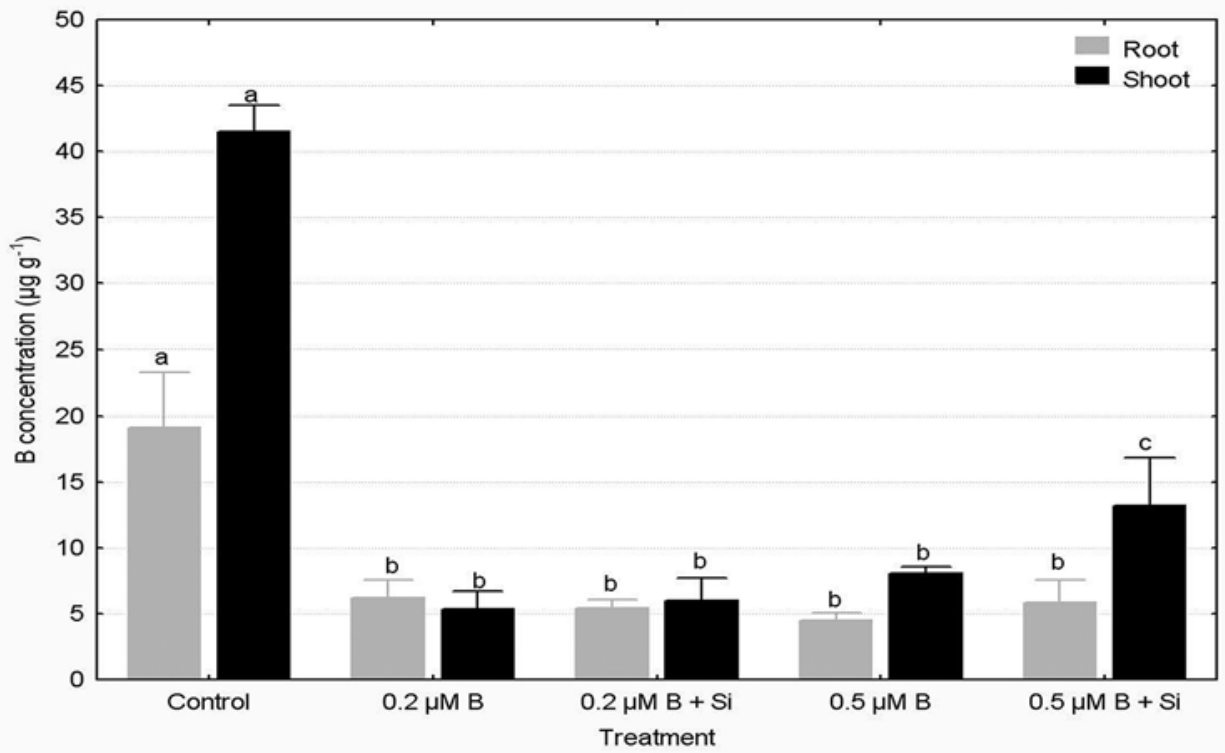

Figure 2: Effect of Si on B concentration in roots and shoots of sunflower plants subjected to low B external supply $(0.2 \mu \mathrm{MB}$ and $0.5 \mu \mathrm{M} B)$. Si concentration in nutrient solution was $1.5 \mathrm{mM}$. Data are means $(n=4) \pm S D$. Significant differences at $P \leq 0.05$ are indicated by different letters. 
$0.2 \mu \mathrm{M}$ B and $0.5 \mu \mathrm{M}$ B treatments and those with Si added were very small. B concentration in shoots was also significantly higher in control compared to all other treatments. At $0.2 \mu \mathrm{M}$ B and $0.2 \mu \mathrm{M}$ B with Si added treatments B concentration in shoot was the same, while Si significantly increased B accumulation in plants grown in $0.5 \mu \mathrm{M}$ B. Our results showed that plants were affected by low B external supply obtaining less than $10 \mu \mathrm{g} \mathrm{g}^{-1} \mathrm{DW}$ except at $0.5 \mu \mathrm{M} \mathrm{B}+\mathrm{Si}$ treatment. According to Bergmann (1992) critical values for B deficiency in sunflower upper fully expanded leaves range between 10 and $13 \mu \mathrm{g} \mathrm{g}^{-1} \mathrm{DW}$, while Blamey et al. (1979) proposed much higher values of around $30 \mu \mathrm{g} \mathrm{g}^{-1} \mathrm{DW}$ in top mature leaf at flowering stage in two sunflower cultivars. Increased B accumulation in plants grown under $0.5 \mu \mathrm{M}$ B with $\mathrm{Si}$ added can be a result of B and Si interaction similar as in study by Liang and Shen (1994). They found that silicon enhance B uptake and accumulation by oilseed rape plants under B deficiency, but increased Si concentration in nutrient solution decrease it under sufficient B supply. In presented study, Si was not measured because we wanted to avoid digestion with HF and separate measurements of B and Si as well. This study was starting experiment for more detail study and we wanted to see the effect of $\mathrm{Si}$ on B uptake and accumulation and growth on sunflower plants under low B supply.

Table 1: Effects of Si supply on mineral element contents in roots of sunflower plants grown in nutrient solutions under conditions of B deficiency $(0.2 \mu \mathrm{M}$ B and $0.5 \mu \mathrm{M} \mathrm{B})$ for two weeks

\begin{tabular}{lccccc}
\hline \multirow{2}{*}{ Treatment } & $\mathrm{P}$ & $\mathrm{K}$ & $\mathrm{Ca}$ & $\mathrm{Mg}$ & $\mathrm{S}$ \\
\cline { 2 - 6 } & \multicolumn{5}{c}{$\left(\mathrm{mg} \mathrm{g}^{-1} \mathrm{DW}\right)$} \\
\hline Control & $8.0 \pm 1^{\mathrm{b}}$ & $32.6 \pm 5^{\mathrm{a}}$ & $7.47 \pm 2^{\mathrm{b}}$ & $3.99 \pm 0.2^{\mathrm{a}}$ & $9.4 \pm 1^{\mathrm{ab}}$ \\
$0.2 \mu \mathrm{M} \mathrm{B}$ & $12.25 \pm 3^{\mathrm{a}}$ & $52.85 \pm 17^{\mathrm{b}}$ & $10.3 \pm 2^{\mathrm{ab}}$ & $2.08 \pm 0.3^{\mathrm{b}}$ & $8.0 \pm 1^{\mathrm{b}}$ \\
$0.2 \mu \mathrm{M} \mathrm{B}+\mathrm{Si}$ & $12.3 \pm 2^{\mathrm{a}}$ & $48.95 \pm 19^{\mathrm{ab}}$ & $12.15 \pm 1^{\mathrm{a}}$ & $2.38 \pm 0.3^{\mathrm{b}}$ & $11.2 \pm 1^{\mathrm{a}}$ \\
$0.5 \mu \mathrm{M} \mathrm{B}$ & $8.0 \pm 1^{\mathrm{b}}$ & $31.9 \pm 10^{\mathrm{a}}$ & $9.4 \pm 1^{\mathrm{b}}$ & $1.95 \pm 0.2^{\mathrm{b}}$ & $10.2 \pm 0.5^{\mathrm{a}}$ \\
$0.5 \mu \mathrm{M} \mathrm{B}+\mathrm{Si}$ & $10.35 \pm 1^{\mathrm{ab}}$ & $38.15 \pm 7^{\mathrm{a}}$ & $7.53 \pm 1^{\mathrm{b}}$ & $1.90 \pm 0.1^{\mathrm{b}}$ & $8.1 \pm 0.5^{\mathrm{b}}$ \\
\hline Treatment & $\mathrm{Fe}$ & $\mathrm{Zn}$ & $\mathrm{Mn}$ & $\mathrm{Cu}$ & $\mathrm{Mo}$ \\
\hline$n_{\text {Control }}$ & $350 \pm 60^{\mathrm{a}}$ & $64.8 \pm 12^{\mathrm{a}}$ & $26 \pm 4^{\mathrm{ac}}$ & $47 \pm 8^{\mathrm{a}}$ & $8.3 \pm 1.1^{\mathrm{a}}$ \\
$0.2 \mu \mathrm{M} \mathrm{B}$ & $322 \pm 25^{\mathrm{a}}$ & $33.3 \pm 7^{\mathrm{b}}$ & $35 \pm 8^{\mathrm{ab}}$ & $44 \pm 14^{\mathrm{a}}$ & $6.7 \pm 2^{\mathrm{a}}$ \\
$0.2 \mu \mathrm{M} \mathrm{B}+\mathrm{Si}$ & $254 \pm 28^{\mathrm{b}}$ & $37.7 \pm 11^{\mathrm{b}}$ & $39 \pm 2^{\mathrm{b}}$ & $45 \pm 5^{\mathrm{a}}$ & $6.8 \pm 1^{\mathrm{a}}$ \\
$0.5 \mu \mathrm{M} \mathrm{B}$ & $295 \pm 15^{\mathrm{b}}$ & $19.4 \pm 4.4^{\mathrm{c}}$ & $20 \pm 0.5^{\mathrm{c}}$ & $42 \pm 4^{\mathrm{a}}$ & $7.5 \pm 0.1^{\mathrm{a}}$ \\
$0.5 \mu \mathrm{M} \mathrm{B}+\mathrm{Si}$ & $315 \pm 5^{\mathrm{ac}}$ & $24.6 \pm 5^{\mathrm{bc}}$ & $39 \pm 11^{\mathrm{b}}$ & $36 \pm 8^{\mathrm{a}}$ & $7.4 \pm 0.1^{\mathrm{a}}$ \\
\hline Da & &
\end{tabular}

Data are means $(n=4) \pm S D$. Different lower case letters within a column denote significant differences at $P<0.05$

Widespread opinion that B uptake by plant roots is mainly passive process at sufficient supply as well as different mechanisms proposed for low supply, including active uptake by root cortex cells as shown for pea and tomato (Savić et al., 2007) should be also taken under consideration. Sunflower was also often used in studies on B uptake, xylem loading and compartmentation. Under low B supply almost all root B is bounded to cell wall (Dannel et al., 1998; Pfeffer et al., 1999; 
Dannel et al., 2000) what could be of great importance for further study of B and $\mathrm{Si}$ interaction in sunflower.

Application of Si had no effect on $\mathrm{P}, \mathrm{K}, \mathrm{Ca}, \mathrm{Mg}, \mathrm{Zn}, \mathrm{Cu}$ and Mo content in sunflower roots (Table 1$)$. Mn content was significantly higher $(p \leq 0.05)$ in treatment $0.5 \mu \mathrm{M}$ B with Si added compared to that with no $\mathrm{Si}$, while $\mathrm{S}$ and Fe were affected by $\mathrm{Si}$ on both ways increasing and decreasing their content at low B treatments. In leaves, Si enhanced accumulation of all nutrients $\mathrm{P}, \mathrm{K}, \mathrm{Ca}, \mathrm{Mg}, \mathrm{S}, \mathrm{Fe}, \mathrm{Zn}, \mathrm{Mg}, \mathrm{Cu}$ and Mo at both B levels $0.2 \mu \mathrm{M}$ B and $0.5 \mu \mathrm{M}$ B. (Table 2).

Table 2: Effects of Si supply on mineral element contents in fully developed leaves of sunflower plants grown in nutrient solutions under conditions of B deficiency $(0.2$ $\mu \mathrm{M} \mathrm{B}$ and $0.5 \mu \mathrm{M}$ B) for two weeks

\begin{tabular}{lccccc}
\hline \multirow{2}{*}{ Treatment } & $\mathrm{P}$ & $\mathrm{K}$ & $\mathrm{Ca}$ & $\mathrm{Mg}$ & $\mathrm{S}$ \\
\cline { 2 - 6 } & \multicolumn{5}{c}{$\left(\mathrm{mg} \mathrm{g}^{-1} \mathrm{DW}\right)$} \\
\hline Control & $4.0 \pm 0.2^{\mathrm{a}}$ & $16.7 \pm 4^{\mathrm{a}}$ & $25.5 \pm 3^{\mathrm{ab}}$ & $4.1 \pm 0.6^{\mathrm{ab}}$ & $5.8 \pm 0.7^{\mathrm{ab}}$ \\
$0.2 \mu \mathrm{M} \mathrm{B}$ & $4.1 \pm 0.5^{\mathrm{ab}}$ & $15.6 \pm 2^{\mathrm{a}}$ & $25.3 \pm 7^{\mathrm{ab}}$ & $3.6 \pm 0.2^{\mathrm{a}}$ & $5.4 \pm 0.2^{\mathrm{a}}$ \\
$0.2 \mu \mathrm{M} \mathrm{B}+\mathrm{Si}$ & $4.7 \pm 0.3^{\mathrm{b}}$ & $17.5 \pm 3^{\mathrm{ab}}$ & $26.1 \pm 6^{\mathrm{ab}}$ & $3.7 \pm 0.6^{\mathrm{ab}}$ & $6.1 \pm 0.5^{\mathrm{ab}}$ \\
$0.5 \mu \mathrm{M} \mathrm{B}$ & $4.2 \pm 0.1^{\mathrm{ab}}$ & $16.0 \pm 2^{\mathrm{ac}}$ & $23.2 \pm 5^{\mathrm{b}}$ & $3.9 \pm 0.5^{\mathrm{ab}}$ & $5.5 \pm 0.6^{\mathrm{a}}$ \\
$0.5 \mu \mathrm{M} \mathrm{B}+\mathrm{Si}$ & $4.6 \pm 1.0^{\mathrm{ab}}$ & $17.8 \pm 1^{\mathrm{bd}}$ & $26.9 \pm 5^{\mathrm{a}}$ & $4.3 \pm 0.5^{\mathrm{b}}$ & $6.5 \pm 0.5^{\mathrm{b}}$ \\
\hline Treatment & $\mathrm{Fe}$ & $\mathrm{Zn}$ & $\mathrm{Mn}$ & $\mathrm{Cu}$ & $\mathrm{Mo}$ \\
\hline Control $_{0.2 \mu \mathrm{M} \mathrm{B}}$ & $80.5 \pm 4^{\mathrm{a}}$ & $31.7 \pm 0.7^{\mathrm{a}}$ & $33 \pm 0.8^{\mathrm{a}}$ & $10.1 \pm 0.4^{\mathrm{a}}$ & $2.1 \pm 0.4^{\mathrm{a}}$ \\
$0.2 \mu \mathrm{M} \mathrm{B}+\mathrm{Si}$ & $58.0 \pm 6^{\mathrm{b}}$ & $29.7 \pm 1.2^{\mathrm{b}}$ & $44 \pm 6^{\mathrm{ab}}$ & $6.7 \pm 0.7^{\mathrm{b}}$ & $1.3 \pm 0.1^{\mathrm{b}}$ \\
$0.5 \mu \mathrm{M} \mathrm{B}$ & $63.7 \pm 12^{\mathrm{b}}$ & $34.3 \pm 2.4^{\mathrm{ac}}$ & $52 \pm 14^{\mathrm{b}}$ & $8.7 \pm 1^{\mathrm{ac}}$ & $1.5 \pm 0.2^{\mathrm{b}}$ \\
$0.5 \mu \mathrm{M} \mathrm{B}+\mathrm{Si}$ & $76.5 \pm 5^{\mathrm{ac}}$ & $27.2 \pm 3.6^{\mathrm{b}}$ & $37 \pm 8^{\mathrm{ab}}$ & $8.0 \pm 0.2^{\mathrm{c}}$ & $1.7 \pm 0.1^{\mathrm{b}}$ \\
\hline Da & $36.3 \pm 33^{\mathrm{c}}$ & $50 \pm 15^{\mathrm{b}}$ & $9.3 \pm 1^{\mathrm{ac}}$ & $2.0 \pm 0.1^{\mathrm{ac}}$ \\
\hline
\end{tabular}

Data are means $(n=4) \pm S D$. Different lower case letters within a column denote significant differences at $P>0.05$

Although differences were significant only in $\mathrm{K}, \mathrm{Ca}, \mathrm{Fe}$ and Mo between treatments $0.5 \mu \mathrm{M}$ B and $0.5 \mu \mathrm{M}$ B with $\mathrm{Si}$ added and in $\mathrm{Zn}$ between both treatments. Similar results were reported by Liang et al., (1994), who found that under low B supply addition of different Si levels had no effect on $\mathrm{P}, \mathrm{Ca}$ and $\mathrm{Mg}$ accumulation in whole oilseed rape plants. Interestingly, in presented study contents of $\mathrm{K}, \mathrm{Zn}$ and Mn were significantly higher in one of treatments with Si added than in control, indication that $\mathrm{Si}$ might also play a role in nutrient deficiency stresses.

\section{CONCLUSIONS}

The results presented here show that Si didn't affect sunflower growth under conditions of low B external supply. Enhancing of B accumulation by addition of Si was present in sunflower leaves at one low B supply. It appears that addition of $\mathrm{Si}$ also affected nutritional status of sunflower, by enhancing accumulation of both macronutrients and micronutrients. Interaction of $\mathrm{B}$ and $\mathrm{Si}$ should be included in 
further investigations with aim to find possible mechanisms involved in uptake and translocation of both elements.

\section{ACKNOWLEDGEMENTS}

This work was supported by the Serbian Ministry of Education, Science and Technological Development (grant ON 173028 to JS).

\section{REFERENCES}

Asad, A., 2002. Boron requirement for sunflower and wheat. J. Plant Nutr. 25: 885-899.

Bergmann, W. (Ed.), 1992. Nutritional Disorders of Plants Colour Atlas. Gustav Fischer Verlag Jena, Stuttgart. p. 386.

Blamey, F.P.C., Mould, D. and Chapman, J., 1979. Critical boron concentrations in plant tissue of two sunflower cultivars. Agr. J. 71: 243-247.

Brown, P.H. and Shelp, J.B., 1997. Boron mobility in plants. Plant Soil. 193: 85-101.

Cakmak, I., Kurtz, H. and Marscher, H., 1995. Short-time effects of boron, germanium and high light intensity on membrane permeability in boron deficient leaves of sunflower. Physiol. Plantarum. 95: 11-18.

Dannel, F., Pfeffer, H. and Römheld, V., 1998. Compartmentation of boron in roots and leaves of sunflower as affected by boron supply. J Plant Physiol. 26: 95-99.

Dannel, F., Pfeffer, H. and Römheld, V., 2000. Characterization of root boron pools, boron uptake and boron translocation in sunflower using the stable isotopes $10 \mathrm{~B}$ and $11 \mathrm{~B}$. Austral $\mathrm{J}$ Plant Physiol. 27: 397-405.

Epstein, E., 1997. Silicon. Annual Review of Plant Physiology and Plant Molecular Biology 50: 641-664.

Pfeffer, H., Dannel, F. and Römheld, V., 1999. Are there two mechanisms for boron uptake in sunflower? J. Plant Physiol. 154: 283-288.

Gunes, A., Inal, A., Bagci, E.G., Coban, S. and Sahin, O., 2007. Silicon increases boron tolerance and reduces oxidative damage of wheat grown in soil with excess boron. Biol Plantarum. 51: 571-574.

Inal, A., Pilbeam, D. and Gunes, A., 2009. Silicon increases tolerance to boron toxicity and reduces oxidative damage in barley. J Plant Nutr. 32:112-128.

Kaya, C., Tuna, L., Guneri, M. and Ashraf, M., 2011. Mitigation effects of silicon on tomato plants bearing fruit grown at high boron levels. J. Plant Nutr. 34: 1985-1994.

Liang, Y. and Shen, Z., 1994. Interaction on silicon and boron on oilseed rape plants. J. Plant Nutr. 17: 415-425.

Ma, J.F., 2004. Role of silicon in enhancing the resistance of plants to biotic and abiotic stresses. Soil Sci Plant Nutr. 50: 11-18.

Ma, J.F., Yamaji, N., 2006. Silicon uptake and accumulation in higher plants. Trends Plant Sci. 11: 392-397.

Marschner, P. (Ed.), 2012. Marschner's mineral nutrition of higher plants. $3^{\text {rd }}$ edition. Academic Press, San Diego, USA. pp. 379-396.

Mengel, K. and Kirkby, E., 2001. Principles of plant nutrition. Boron. Kluwer Academic Publishers.

Öztürk, Ö., Ceyhan, E., Önder, M., Harmankaya, M., Hamurcu, M. and Gezgin, S., 2010. Micronutrient contents in leaves of sunflower cultivars grown with different boron doses. Helia 33: 215-230.

Reddy, N.Y., Shaanker, U.R., Prasad, T. and Kumar, U.M., 2003. Physiological approaches to improving harvest index and productivity in sunflower. Helia 26: 81-90.

Rogalla, H. and Römhled, W., 2002. Effect of silicon on the availability of boron: possible effects on the phenol pathway and on the redox status in Cucumis sativus L. In: Goldbach, H., Rerkasem, B., Wimmer, M., Brown, P.H., Thelier, M. and Bell., R. (Eds.), Boron in Plant and Animal Nutrition. Kluwer, Dordrecht, The Netherlands, pp. 205-2011. 
Römheld, V. and Marschner, H., 1991. Functions of micronutrients in plants. In: Mordvedt, F.R., Cox, F.R., Shurman, L.M. and Welch, R.M. (Eds.), Microelements in Agriculture. $2^{\text {nd }}$ ed. (Eds. SSSA Book Series, No.4), Madison, WI, USA. pp. 297-328.

Savić, J., Nikolić, M., Prodanović, S. and Römheld, V. 2007. Boron uptake by the root cortex symplast of tomato and pea plants: evidence for low-boron induced active transport. Funct. Plant Biol. 34: 1130-1136.

Savić, J., Römheld, V. and Nikolić, M., 2012. Oilseed rape (Brassica napus L.) genotypic variation in response to boron deficiency. Turkish Journal of Agriculture and Forestry 36: 408-414.

Shorrocks, V., 1997. The occurrence and correction of boron deficiency. Plant Soil 193: 121148. 